\title{
How Can Flipped Classroom Develop Critical Thinking Skills? A Literature Review
}

\author{
Benedecta Indah Nugraheni, Herman Dwi Surjono, and Gregorius Punto Aji
}

\begin{abstract}
This review aimed at providing a comprehensive overview of how the flipped classroom can give the positive effects on developing students' critical thinking skills. Data were collected from four databases, which included Google Scholar, ResearchGate, EBSCO, and Emerald. This study synthesized the findings of 16 studies published from 2015 to 2020. The results revealed that there were many learning activities that could be designed in a flipped classroom both outside and inside the classroom so that it allowed students to be actively involved in learning, flipped classrooms could also be integrated with other learning methods and utilize various technologies to increase their effectiveness in developing students' critical thinking skills.
\end{abstract}

Index Terms-Critical thinking, flipped classroom, flipped learning.

\section{INTRODUCTION}

Flipped classroom (FC) is a form of blended learning which has become popular as a learning model [1], [2]. FC reverses the learning activities of learners, in which activities that are usually carried out in groups in the classrooms are diverted into outside classroom activities, and activities that are usually carried out outside of individual classes are diverted into the classroom activities. Learning activities outside the classroom are carried out before learning in the classroom with learning materials provided by educators with the help of information and communication technology, for example in the form of videos delivered through the Learning Management System (LMS), or other platforms. Class time that is normally used for listening to lectures is diverted to activities and application of knowledge, which are used as homework. Classroom activities can be in the form of problems solving, discussions, analyzes, and good interactions with other students [3]-[7].

A FC-based learning model allows educators to use more opportunities to involve students to apply their knowledge, and interact with educators and peers to share knowledge and ideas, so as to improve their higher-order thinking and communication skills [8]. Implementing FC, teachers can also facilitate students to develop critical thinking (CT) skills

Manuscript received June 17, 2021; revised July 26, 2021.

Benedecta Indah Nugraheni is with the Graduate Program of Yogyakarta State University, Yogyakarta, Indonesia 55281; and the Faculty of Teacher Training and Education of Sanata Dharma University, Yogyakarta, Indonesia (e-mail: benedectaindah.2020@student.uny.ac.id, ben_indah@usd.ac.id).

Herman Dwi Surjono is with the Graduate Program of Yogyakarta State University, Yogyakarta, Indonesia (e-mail: hermansurjono@uny.ac.id).

Gregorius Punto Aji is with the Faculty of Teacher Training and Education of Sanata Dharma University, Yogyakarta, Indonesia (e-mail: punto@usd.ac.id). and increase participation in learning, achievement and satisfaction in learning [9], [8]. In addition, FC provides enough time for educators to provide more personal feedback and assistance to students, as well as receiving feedback from students and knowing what materials are not understood by the students [10].

FC can be applied at all levels of education. The application of FC, which was initially widely implemented in primary and secondary schools $(\mathrm{K}-12)$, is currently also being developed in universities [3], [11], [12]. FC has become popular in universities because of the advantages it can provide [13]. Based on many studies, it has been found that FC is more effective compared to traditional learning methods, and provides a significant difference in learning outcomes of learners [14]. This indicates that FC can create a deep learning environment, meaningful learning, development of CT, and advanced learning [13]. Previous studies reported that $\mathrm{FC}$ had a potential effects on promoting student's CT [15].

The results of research on the application of FC and the development of CT have been published in many scientific journals. However, research on the applications of FC to develop CT has not been extensively conducted. Although previous reviews analyzed the applications of the FC, a literature review of the application of FC to develop CT in both high schools and colleges has not been published yet. There is a lack of literature review to examine the effects of FC on developing CT and cover all studies from 2015 to 2020. This review is intended to fill the above research gap.

\section{DeVEloping CRITICAL ThINKING SKILlS}

CT is a concept that is important to consider in education. This concept has been developed for centuries, and it has come to the conclusion that $\mathrm{CT}$ is a necessity for humans, so that everyone is encouraged to become a critical thinker [16]. In education, CT is not the only objective that is separated from other important parts and is seen as one of the most important competencies for students to develop [13]. CT as one of the skills needed in the 21 st century is very important to develop especially to prepare students to be able to attend education at the next level and when they enter the world of work [17]. Therefore, it should become one of the responsibilities of teachers and material developers to provide opportunities for students to develop CT [16], through various subjects/courses. Learning should not only focus on mastering the material, but also need to provide space to develop various life skills needed by students.

There is a variety of CT definitions in many literature [18]. One of them was suggested by Facione [19]. He states that 
CT is categorized as cognitive skill that essentially comprises self-regulation, inference, analysis, interpretation, explanation and evaluation. Thinking critically can be included in learning through various academic disciplines, by directing the focus of learning, so that it is more thinking-skills-based [20]. These skills are developed by involving students in active learning, engaging them in high-level problem-solving skills and giving them chances to participate in team activities [21].

Active learning is one of the characteristics of FC. Implementing FC, teachers can provide more time to integrate and apply the knowledge that students already have had, through a variety of student-centered and active learning strategies. Active learning is related with improved students' academic performances, increased students' engagements, CT, and better attitudes towards learning [9]. Based on this reason, FC is considered to have the potential to develop students' CT.

\section{Methodology}

\section{A. Research Questions}

The purpose of this article is to provide an overview of how the application of FC can develop CT effectively. Therefore, the following research questions are proposed:

1) What learning activities and technology are used in FC to develop CT?

2) What teaching approaches are used in FC to develop CT?

3) How have the applications of FC influenced the development of CT?

\section{B. Types of Research}

This research was conducted through content analysis of 16 research articles on the application of FCs to develop CT skills in high schools and colleges, which have been published in scientific journals from 2015 to 2020. McMillan argues that content analysis is a research method that is usually applied in the social sciences and humanities. Content analysis, according to Creswell, is “ “... a method of studying the content of written texts, artifacts, images and recordings" [22]. This study uses content analysis because, according to Falkingham \& Reeves, this method can analyze and interpret various published articles, including development categories, calculation of frequency, and stages of careful interpretation. Bauer also states that the use of content analysis can link data related to one another and analyze topics that readers can read efficiently, and can be used by researchers as a reference for further researches [22].

This content analysis is carried out by following certain steps. According to [23], content analysis refers to analyzing material which is carried out through a step-by-step process. The steps that must be taken are as follows: First, it formulates the material to be analyzed based on theoretical studies and research questions. Second, the researcher selects journal articles from various fields of study that discuss the development of CT skills using FC in high schools and higher education, published in 2015 to 2020. Third, the researcher analyzes the main topics that have been determined, including FC designs to increase CT skills of students in high schools and colleges and the measurement of students' CT skills. The analysis results are interpreted using descriptive analysis, percentage, and frequency to interpret the findings and get the categories that are most often done in the CT skills development using FC. Fourth, the data are analyzed and reported systematically. Fifth, conclusions are made and suggestions for further research are made to contribute to the further discussions and research on developing CT skills using FC.

\section{Literature Search and Selection}

Literature has been searched through several sources, namely: Google Scholar, ResearchGate, Ebsco, and Emerald. The keywords used for searching are "flipped classrooms and critical thinking", "flipped learning and critical thinking", and "inverted classrooms and critical thinking". The range of years is from 2015 to 2020 .

The articles were selected using inclusion and exclusion criteria [24]-[26]. The selected articles were those that had the following criteria: a) articles reporting the results of research on the application of FC to developing $\mathrm{CT}$; b) researches carried out in high school or college levels; and c) empirical studies. Articles that were excluded were articles that: a) did not describe the learning process either outside the classroom or face to face in the classroom; b) were published in proceedings; and c) non-English articles. Based on these criteria, in the end, 16 articles were selected.

\section{RESUlTS}

The articles reviewed were the results of research conducted in junior high school [27], [28], senior high school [13], [29], [30], and higher education [8], [15], [31]-[39] levels in different countries (Hong Kong, South Africa, USA, Malaysia, Taiwan, England, Iran, Palestine, Vietnam, Indonesia, and Philippines). The results of the review are presented in Table 1 (the order of articles is based on the year of publication) and described based on the research questions, as follows:

\section{A. Student Learning Activities and Technology Used in FC to Develop CT}

In FC, student learning activities are divided into two parts, namely outside the classroom and inside the classroom. Most of the learning activities outside the classroom (pre-class) are carried out by watching video, and partly equipped with PowerPoint presentations, screen casts and podcasts, online content such as websites, articles, taking note, taking online quizzes, solving given problems, reviewing questions, computer simulation, and assignments. In addition, there are also those who study with online reading, making a mind map from audio and text, summarizing what they had learned, inquiring, identifying and proposing questions, previewing materials, reflecting on the learning process, and brainstorming topic scopes.

Learning activities that are mostly done in face to face flipped class are discussions and presentations. Other activities are solving more advanced problems, drawing mind maps, answering worksheet questions, practicing what has been learned from the online units, creating student's own 
concept, videos, quizzes, and reflection, and answering open ended questions.

Some articles described learning activities carried out by students after class or after each lesson, namely: post-task quizzes and self-reflection activities, online group discussions, extended learning in discussions and refining mind maps [27], determine the project topic, make a schedule, carry out the project, upload the project, and prepare for the next lesson [38], project work, and reflection [28].

TABLE I: LEARNING ACTIVITIES AND TECHNOLOGY USED IN FLIPPED CLASSROOMS, AND RESULTS

\begin{tabular}{|c|c|}
\hline Article & $\begin{array}{l}\text { Level of education, year of students, } \\
\text { course, and aim/research question, }\end{array}$ \\
\hline [27] & $\begin{array}{l}\text { Conducted in a junior secondary school } \\
\text { students (N=124) in Hong Kong for three } \\
\text { years, from grade } 1 \text { (aged } 12 \text { to } 13 \text { ) to } \\
\text { grade } 3 \text { (aged } 14 \text { to } 15 \text { ), in Integrated } \\
\text { Humanities subject. } \\
\text { Aim: To explore the result of CT learners' } \\
\text { achievement when the CT development is } \\
\text { incorporated into the teaching of subject } \\
\text { with pedagogical and technological } \\
\text { support. }\end{array}$ \\
\hline
\end{tabular}

\section{Learning activities and technology}

1. Pre-class/“'Online pre-Lesson Learning”: (a) retrieve pre-lesson worksheets for understanding lesson goals and creating pre-lesson mind maps; (b) brainstormed topic scopes, draw mind maps, and read online readings.

2. In-class/"Lesson Learning": (a) access textbook, websites, and presentation files selected for group learning task and draw mind maps; (b) complete the worksheet guided by the paper-based textbook and the provided e-learning resources.

3. After each lesson/“Post-lesson Learning Consolidation": (a) retrieve selected learning outputs and references for post-task quizzes and self-reflection activities, online group discussion; (b) extended learning discussions and refined mind maps.

Technology: Mobile technology, the school-based e-learning platform, and Google Docs.

[31] Conducted at a South Africa university.
The sample for this study was all the second year education students $(\mathrm{N}=28)$ with mathematics as a major, when they learned introductory algebra.

Aims: To promote the CT dispositions of mathematics students, to develop their understanding of mathematical concepts, to foster responsibility for their understanding of knowledge and skills, and to provide chances for active learning through discovery and engagement with learning materials using FC.
1. Pre-class: watch video, solve given problems.

2. In-class: discussion of difficult concepts, create student's own concept videos (as a group activity), solve more advanced problems individually and in groups, reflect on their problem solving.

Technology: The FC pedagogical approach and model was used as an intervention. Tools used for in-class/out-class activities didn't mention in the article.
Instruments, methods for analysis, and results Instruments: Seven critical thinking tests and five semi-structured interviews with teachers and students.

Analysis: Comparing means of students learning outcomes from all critical thinking tests in the three-year study.

Results: The students performed well in the tasks of identifying hypotheses, induction and deduction; and some achievements in the explanation and evaluation tasks. Students required more time to promote capacities of deduction, explanation and evaluation. Both teachers and students appreciated the pedagogical way of giving guidance for sharing groups of students to encourage the development of CT skills.

\author{
Instruments: Closed questionnaire (Likert \\ scale). \\ Analysis: Mixed method: A quantitative \\ survey and qualitative research. \\ Results: FC seems to be a viable teaching \\ methodology for the math classes. FC \\ contributes to the encouragement of CT \\ dispositions through interaction, \\ problem-solving strategies and preparation \\ by the students. Students' knowledge of \\ mathematics had improved and FC \\ supported their learning and higher-order \\ cognitive skills. FC also encouraged the \\ students to take responsibility for their own \\ learning and students' problem solving \\ strategies. \\ Instrument: The level of critical thinking \\ was assessed with comparing the exams of \\ flipped model (in 2014) with a traditional \\ lecture (in 2007 and 2011). \\ Analysis: two-way ANOVA, t-test, and \\ f-test. \\ Result: A key finding of this research is that \\ a FC approach allows more time provided to \\ active learning and transitioning assessment \\ questions to incorporate additional \\ higher-order thinking activities.
}

[33] Conducted at a university in Taiwan, for the students taking Introductory Educational Psychology courses $(\mathrm{N}=85)$. The research question: What is the effect of facilitating CT using the "Collaborative Questioning, Reading, Answering, and Checking" (C-QRAC) collaboration script on immediate and delayed science reading literacy in collaborative learning with ICT supports in FC conditions? (1 of through Lecture Tools.
2. In-class: Review common misconceptions/the most difficult concepts and asked questions requiring higher-order thinking, and five graded case studies. Work together both in laboratory and lecture Teamwork included laboratory dissection, case studies, team assessment appeals, and team quizzes.

Technology: Institution's course management system (Canvas Instructure), short YouTube animations, and Lecture Tools technology to display question to students.

1. Pre-class: introduction to CT (100 mins) and preview materials on brain functions, memory, and learning (week 1).

2. In-class:

a. Week 2: test of prior knowledge (10 mins), Google Docs training (20 mins), the CT infused Q-RAC task (60 mins), break (10 mins), immediate science reading literacy test (20 mins). b. Week 3: delayed test and the follow-up
Instruments: 24 multiple-choice items and 4 constructed-response items.

Analysis: Descriptive statistics, independent and paired samples t-tests, and repeated-measures analysis of variances (RM-ANOVA).

Results: New insights in the design of FC to facilitate CT in science learning with ICT. Researcher suggest the application of the C-QRAC collaboration script to facilitate 


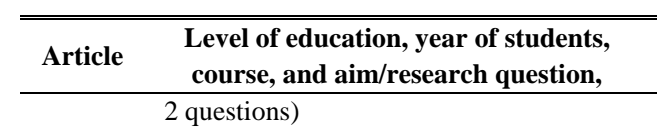

[34] Conducted at a college in Birmingham to analyze the effect of FC in three courses, namely: 1) Introductory cell and molecular biology course ( $\mathrm{N}=52) ; 2)$ Intermediate-level evolutionary ecology course ( $\mathrm{N}=27) ; 3)$ Intermediate/ upper-level biochemistry course $(\mathrm{N}=21)$, with a majority being freshmen and sophomores.

Aim: To assess the impact of flipped instruction and active learning on development of CT skills in undergraduate life science students using a valid and reliable measure of CT.

\section{Learning activities and technology}

attitude survey (30 mins).

Technology: Google Docs for online

collaboration and for editing the study notes via a smartphone.

1. Pre-class: watch videos and computer simulations as well as quizzes to introduce content.

2. In-class: case studies, small-group problem sets, model building, clicker-based think-pair-share strategies, process-oriented guided-inquiry learning, and targeted CT exercises.

Technology: Web-based videos were used by each instructor to flip some aspect of the course in order to implement active-learning exercises during class meetings.

Instruments, methods for analysis, and results

students' CT and promote their self-directed learning in $\mathrm{FC}$ conditions.

Instruments: Critical Thinking Assessment Test (CAT). The CAT results were compared with self-reported, perceived learning gains through a Likert-scale survey implemented through the Student Assessment of Learning Gains (SALG) site, both in a pretest/post-test design. Analysis: Significant differences (in mean pretest and post-test scores ) were assessed using paired, two-tailed, Student's $t$ tests. Result: The application of active learning strategies in the FC can be beneficial for CT. Comparison of the mean pretest and post-test scores across the three courses revealed gains consistent with the interpretation that active learning in the FC enhances the development of CT skills.

[15] Conducted at a university in Iran, on the second-year bachelor's nursing students who had signed up for the Musculoskeletal Medical-Surgical Nursing theoretical training course $(\mathrm{N}=85)$.

Aim: To compare the effects of traditional lecture and FC on Iranian nursing students' CT disposition.
1. Pre-class: Textbook, PowerPoint presentation slides and short video clips lectures.

2. In-class: have a quiz with 3-5 questions and then conduct group discussions in groups of 3-5 students and information exchange among groups.

Technology: DVDs consisting of electronic contents in PowerPoint presentation slide with recorded sound and short video clips.

\section{Pre-class: video lectures.}

2. In-class: ask and answer question, discussion, presentation, shares ideas.

Technology: Video lessons developed by the researcher through Facebook groups outside school hours.
Instruments: Demographic questionnaire and Ricketts' CT Disposition Inventory on a Likert-scale (33 items), via pretest and post-test design.

Analysis: Descriptive statistics measures and paired-sample $t$, independent-sample $t$, and Chi-square tests and also the multivariate analysis of variance.

Result: FC group were significantly better than the traditional lecture group. Instruments: California CT Skills Test before (pretest) and after (post-test) the implementation of FC.

Analysis: Descriptive and inferential statistics (t-tests and ANCOVA test) to determine the differences between the groups.

Results: FC was effective compared to the traditional method, with respect to the students' CT skill.
Instruments: Lecturer and students reflection, observation, checklist, and interviews to the students.

Analysis: These qualitative data were coded and analyzed using thematic analysis. Result: The use of FC has developed students' communication and CT skills.
[35] Conducted at a university in Malaysia in Accounting subject $(\mathrm{N}=49)$.

Aim: To examine how the use of FC can help to improve communication and CT skills in problem solving among students taking the accounting subject.

\section{Pre-class: video lectures and questions on} the topic to be discussed in class.

2. In-class: (a) reflections on the video and how they think FC will help to understand more on the topic; (b) presentations and discussions; (c) evaluation and analysis on the presentations and discussions; (d) reflections from the students by answering open ended questions.

Technology: Videos uploaded to university's Online Learning

[36] Conducted at a university in Hawaii, United States, especially in Critical Thinking \& Analysis course $(\mathrm{N}=158)$. Aim: To examines a CT course developed as part of a General Education curriculum to enhance students' CT skills.

1. Pre-class: video lectures and take note, take the online quizzes.

2. In-class: practice what was learned from the online units (apply the skills and explore a central course theme), discussion.

Technology: The online learning modules embedded in learning management system (LMS).

\footnotetext{
Instruments: 1) A short multiple-choice test (pre and post-test); 2) The California Critical Thinking Skills Test (CCTST); and 3) Focus groups given orally with the audio recorded (to investigate what students thought of the FC model).

Analysis: Paired t-test, an independent two sample t-test, and a linear regression. Result: FC and mixed model was an effective method for improving students' CT skills.

Instruments: Homework, in-class tasks and specific situations tasks.

Result: Students can better regulate their learning and understanding with their peers' views so that when students give their opinions they will be able to give sound evidence, not only accepting the reasoning of other individuals. It means that students
}

[13] Implemented in Vietnamese high schoo for Grade 11 students using thematic teaching on the topic "The Use of Cosmetics in School - Risks to be Learned".

Aim: To present such FC model and its application in the thematic teaching to promote CT for learners.

\section{FC model:}

1. Introduce task: Presentation of tasks, introduction of achievements and preparation of learning activities.

2. Out-of-class Task: Students study the learning contents including screencasts and podcasts, PowerPoint slides, or use online material such as websites, videos, and 


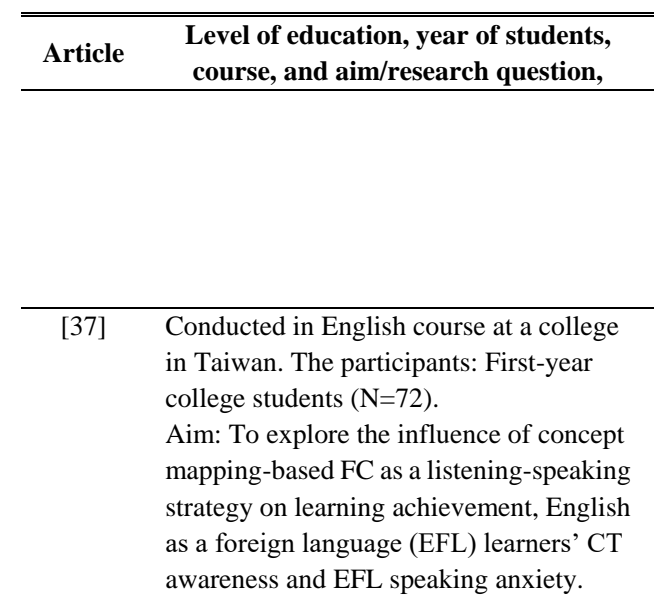

Learning activities and technology

articles.

3. Assess learning: Online question and answer for self-assessment.

4. In-class activities: Teamwork and learner-to-learner and learner-teacher dialogue.

1. Pre-class: Watch videos on Moodle and posted their reflections.

2. In-class: an interactive discussion over meaning interpretation and content clarification, construction of a concept map with peers, group presentations, and doing individual oral reports in front of class. Technology: Moodle providing access to lecture documents, discussion, homework, and examinations from the Internet.
Instruments, methods for analysis, and results have CT.

Instruments: 1) Listening comprehension tests (25 multiple choice items); 2) Speaking tests (3 sets of questions); 3 ) The survey questionnaire of the students' critical thinking; 4) Speaking anxiety questionnaire (12 items); 5) The Closeness Index Concept-Mapping for Scoring. Analysis: Covariance (ANCOVA) and paired-samples $t$ test.

Results: Concept mapping-based FC significantly improved students' learning performance and CT awareness, and minimized speaking anxiety in an EFL setting compared to the conventional-based FC instruction. There were correlations between concept mapping, learning performance, and CT. A significant negative relationship between speaking anxiety and the other variables was also revealed.
[38] Conducted at a higher education in Indonesia. The participants were students in Science Education ( $\mathrm{N}=38)$. The material was The Substance Change. project-based learning model on student's CT ability. Aim: To know the effect of the FC and the

\section{Pre-class: (a) begin with the essential} question, learn video; (b) collect data, make a project.

2. In-class: (a) present and share the problem, make a plan for the project; (b) present the product.

3. After class: (a) determine the project topic, upload the project, prepare for the next lesson.

Technology: Video and website provided by the lecturer.

\section{[39] Conducted at a university in Carolina,} United States, especially in a third-semester German language course $(\mathrm{N}=12)$.

Aim: To propose using the FC approach to promote critical cultural awareness by developing cross-cultural CT skills. make a schedule, (b) carry out the project,
1. Pre-class: (a) studying the content presented on worksheet and entered the information gleaned from their preparation at home, (b) studying additional materials, such as supplemental reading/PowerPoint slides and video, available on Blackboard, LMS.

2. In-class: group activities (e.g., cultural discussions, compare the answer in the worksheet to other teams), and the instructor provided answer as needed.

Technology: Worksheets, hyperlinked on the worksheets and the institutional LMS. Instruments: Pretest and post-test, observation, and questionnaire. Analysis: A paired sample t-test to compare mean scores of pre-test and post-test. Results: The combination of FC and Project-Based Learning Model give a positive effect on student's CT ability. The models supported an effective, interesting, and the student-centered learning process.

Instruments: Two surveys conducted in four weeks into the semester and two weeks prior to end of the semester.

Analysis: descriptive and reflective analysis.

Results: FC approach gives chances to promote the higher-order thinking skills which are important to enhance cross-cultural critical awareness. CT about another culture also encourages critical analysis of one's own culture, along with its advantages and disadvantages.

[28] Conducted at a private language institute in Iran. The participants were the intermediate English as a Foreign Language (EFL) learners $(\mathrm{N}=40)$, with age range from 14 to 16 .

Aim: To know the effects of FC on improving Iranian EFL learners' listening comprehension and CT.

1. Pre-class: Watch videos and online quizzes.

2. In-class: (a) focus on receiving students response by recalling the basic knowledge (by answering or asking question, online quiz) (15-20 mins); (b) focus on engaging students with active learning and CT (e.g., 3-2-1, conversations, write-pair-share, idea mapping, comparison/sharing of notes, jigsaw, minute documents, teaching learning, three-step interview, fishbowl).

3. Post-class: project work and reflection.

Technology: Internet, computer, and projector.

Participants used their smartphones during learning.

[8] Conducted at a nursing university in

1. Pre-class: Recognize the key Northern Taiwan. The subjects were the problems/concepts and take notes by watching online instructional videos, summarize what they had learned and Training (Nursing case-based training course) $(\mathrm{N}=36)$. identified, propose questions, think diversely, inquire by in-depth thinking or
Test (OQPT); 2) listening comprehension pretest and post-test (40 items); 3 ) six questions for interview; and 4) critical thinking questionnaire using Likert-scale (30 items).

Analysis: Independent and paired sample t-test. The CT mean scores was compared using paired sample t-test.

Result: There were significant differences in learning English listening comprehension and $\mathrm{CT}$ between experimental (FC) and control group (traditional classroom).

Instruments: Pre-questionnaires and post-questionnaires (Likert-scale). Analysis: ANCOVA to compare students' CT skills of the two groups. Results: The students' CT scores of the experimental group were significantly
Instruments: 1) Oxford Quick Placement 


\begin{tabular}{|c|c|c|c|}
\hline Article & $\begin{array}{l}\text { Level of education, year of students, } \\
\text { course, and aim/research question, }\end{array}$ & Learning activities and technology & $\begin{array}{l}\text { Instruments, methods for analysis, and } \\
\text { results }\end{array}$ \\
\hline & $\begin{array}{l}\text { (Recognize, Summarize, Inquire)-based } \\
\text { flipped approach better promote the } \\
\text { nursing students' CT in neonatal } \\
\text { assessment than the traditional flipped } \\
\text { approach? }\end{array}$ & $\begin{array}{l}\text { seeking evidence, make reflections on the } \\
\text { learning process, and find potential } \\
\text { problems regarding what they have learned. } \\
\text { 2. In -class: Make decisions on several medical } \\
\text { cases guided by the teacher, and also } \\
\text { practice relevant nursing skills. } \\
\text { Technology: RSI-based flipped approach } \\
\text { through the online learning system. }\end{array}$ & $\begin{array}{l}\text { higher compared to the control group. } \\
\text { RSI-based FC developed the students' } \\
\text { learning achievement, CT, self-efficacy, } \\
\text { and satisfaction more than the traditional } \\
\text { case-based training did. }\end{array}$ \\
\hline [30] & $\begin{array}{l}\text { Conducted at a senior high school in } \\
\text { Philippines, to learners of English as a } \\
\text { Second Language (ESL) }(\mathrm{N}=212) \text {. } \\
\text { Aim: To find out if FC can also be used } \\
\text { effectively in teaching English as a second } \\
\text { language with special focus on improving } \\
\text { (1) CT levels, and (2) reading } \\
\text { comprehension levels. }\end{array}$ & $\begin{array}{l}\text { 1. Pre-class: Learning through videos, audio } \\
\text { and text pre-uploaded in a selected online } \\
\text { repository. } \\
\text { 2. In -class: (no description in this article). } \\
\text { Technology: Videos, audio, and text uploaded } \\
\text { in online repository like Facebook. }\end{array}$ & $\begin{array}{l}\text { Instruments: Lauren Starkey's CT Test } \\
\text { through pretest and post-test. The test } \\
\text { consisted of } 30 \text { items of multiple choice. } \\
\text { Analysis: Independent sample t test was } \\
\text { used to know whether the mean scores of } \\
\text { the FC approach and the lecture discussion } \\
\text { approach were significantly different. } \\
\text { Results: There were improvements in the } \\
\text { CT levels and the reading comprehension } \\
\text { levels of the respondents. However, the } \\
\text { respondents who received instruction using } \\
\text { the FC approach significantly outperform } \\
\text { the respondents who received traditional } \\
\text { instruction. }\end{array}$ \\
\hline
\end{tabular}

\section{B. Teaching Approaches Used in Flipped Classroom to Develop $C T$}

Several approaches (including strategies, models, methods), applied in FC to support the development of CT, included "Collaborative Questioning, Reading, Answering, and Checking" (C-QRAC) collaboration script [33], concept mapping-based flipped learning approach [37], RSI (Recognize, Summarize, Inquire)-based flipped approach [8] project-based learning model [38], active learning through discovery and involvement with materials [31], and active learning exercises [34], “... combining collaborative learning with the technique of using Socrates' questioning method and Bloom's taxonomy in designing homework and in-class activities" [13]. One study emphasizes pedagogical and technological (mobile technology) supports [27].

\section{The Influences of the Applications of FC on Developing $C T$}

In general, the reviewed articles reported that the application of FC can improve CT. Through quasi and true experimental research design, the result of pre-test and post-test revealed that CT tests score of experiment group, which used FC instruction, statistically significant different form the control group, which used conventional/traditional instruction [15], [29], [37], [28], [30]. In the quasi experimental with one group time series design showed that after the implementation of the FC and project-based learning model, the average CT score of post-test was significantly different from the pre-test [38].

The assessment of CT via pre-test and post-test after implementing active learning in FC [34] and explicit CT teaching methods with the flipped design showed that there was a statistically significant increase between pre-test and post-test scores [36]. The study with a single-group, post-test-only design reported that FC pedagogical approach and model contributed to the encouragement of CT dispositions through interaction, problem-solving strategies and the students' preparation [31]. Other studies using qualitative action research methodology [35] and explorative study [8] also gave the results that students' CT skills have been increased with the implementation of FC.

\section{DISCUSSION}

This literature review analyzes the application of FC to develop student CT in high schools and colleges which is applied to various disciplines, including integrated humanities, mathematics, biology, educational psychology, ecology, biochemistry, nursing, accounting, thematic, science education, physics, English, and German language. Several research methods were used to determine the influences of FC on CT. Of all the articles reviewed, it was reported that the application of $\mathrm{FC}$ had a positive influence on the development of students' CT, and it was more effective than the traditional classroom.

Active learning and learner-centered strategies are required to promote critical thinking skills [15]. Based on previous literature reviews, FC approach develops an active learning environment [40]. From the results of the review it is known that by implementing FC there are various learning activities that can be designed for students both outside and inside the classroom. Learning activities outside the classroom as the preparation for face-to-face meetings in class, gives students the opportunity to learn actively. Thus, FC can be designed to produced a meaningful and active learning experience, not only in-class as it happens in traditional FC, but also in out-of-class learning [41]. The literature has showed the importance of the pre-class stage in FCs. Several researchers have pointed that students' pre-class learning status could influence their in-class learning outcomes, including the learning tasks related to problem solving and CT [13]. The discussion and activities used the outside classroom activities to provide opportunities for the students to develop their CT [30].

By reversing learning activities, $\mathrm{FC}$ has sufficient time in the classroom to facilitate learning that involves students actively, through various learning activities as found in this review. The data of a research verify that the FC approach 
allowed more time for a transition of assessment questions and activities focusing on CT [32]. In a FC, the instructor's lecturing time is minimized whereas activities are designed to activate CT through peer collaboration [33]. Most of the class time is focused on active learning strategies for problem solving, case studies, labs, games, simulations, experiments, collaborating and engaging with peers, and evaluating their progress [31], [34], [42]. Many studies have found that students need instructional activities with active learning to practice CT skills. The flipped model can work well to teach CT by bringing active learning into the classroom. Active learning is a process that encourage analysis, synthesis, and evaluation of the class content through students engagement in activities, such as discussion, problem solving, reading, or writing [36].

From the articles reviewed it was found that some researchers integrated specific learning approaches to support the development of CT. In practice, several flipped models with different focuses have been proposed and implemented in many disciplines [40]. In implementing FC, teachers have the opportunity to determine learning strategies that are appropriate to the learning environment and student characteristics. Therefore, to optimize its potential in creating effective learning, FC can be integrated in one or more other teaching strategies [43], for example, problem-based learning, collaborative learning, and inquiry-based learning [40]. By utilizing technology teachers can modify the conventional FC to provide various content delivery [2] so that this becomes an innovative FC model [40]. This also the FLIPPED model that provide progressive activities, engaging experiences, and diversified platforms [44].

Various learning activities carried out by students both at the outside class and in-class, as well as the integration of various strategies in FC can increase student involvement and create active learning that supports the development of CT. Learning activities that provide students the opportunity to learn at their own pace, allow them to collaborate with their classmates, and let them raise concerns and clarifications in a timely manner can be considered as effective ways to develop their CT (30). Thus, FC is a potential learning model to encourage the development of CT skills in a comprehensive manner by emphasizing student-centered learning. This happens because the learning process in FC is determined by the preparations made by students outside the classroom [27].

From this review it is believed that FC is a strategy that is capable of developing CT effectively, but this study is only limited to the results of researches that meet the criteria for this review. There are several other research results on the influences of FC on the development of CT that give different results. These quasi-experimental studies [45]-[49] reported that there was no statistically significant difference between the class using FC and the traditional class on CT. $\mathrm{FC}$ is no more effective than traditional classes in improving CT. Although some of these studies have showed that FC was not a significant factor in increasing $\mathrm{CT}$, it has been recognized that $\mathrm{FC}$ has a positive impact on several other variables, such as peer interaction, student's openness, and student engagement.

Although some of these studies showed that FC was not an effective strategy in improving CT, this literature review provides a complete description as well as a logical explanation of how FC can improve CT effectively. This information is useful for future studies that will implement FC to develop CT. In addition, the description also provides insights to help discover new, unresearched and important topics to discuss related to FC implementation.

\section{CONCLUSION}

This study has showed that FC is an effective learning model for developing CT both in high schools and in higher education level. In order to optimally develop CT, FC needs to be designed so that it can create active learning by determining various learning activities both outside and inside the classroom, integrating other methods, and utilizing technology. Future research could investigate the other influences of FC that have not been widely studied, for example on student learning responsibilities and student self-regulation.

\section{CONFLICT OF INTEREST}

The authors declare no conflict of interest.

\section{AUTHOR CONTRIBUTIONS}

Benedecta Indah Nugraheni found the topic, selected article to be reviewed, identified and categorized data, analyzed data, make conclusion, and wrote the first draft of the paper. Herman Dwi Surjono suggested article to be reviewed and framework for analysis, and reviewed the analysis and discussion. Gregorius Punto Aji reviewed and edited the language, suggested some articles to be reviewed, help to categorized the data, make analysis and draw conclusion. All authors had approved the final version.

\section{REFERENCES}

[1] H. Staker and M. B. Horn, "Classifying K-12 blended learning," Innosight Institute, May 2012.

[2] J. Bergmann and A. Sams, Flip Your Classroom: Reach Every Student in Every Class Every Day, International Society for Technology in Education, 2012.

[3] K. Ash, "Educators view the "flipped" model with a more critical eye," Education Week, pp. S6-S7, August 2012.

[4] J. Nouri, "The flipped classroom: For active, effective and increased learning - Especially for low achievers," International Journal of Educational Technology in Higher Education, vol. 13, no. 33, pp. 1-10, August 2016.

[5] J. Bergmann and A. Sams, "The flipped classroom," CSE, vol. 17, no. 3, pp. 24-27, 2013/2014.

[6] Z. Unal and A. Unal, "Comparison of student performance, student perception, and teacher satisfaction with traditional versus flipped classroom models," International Journal of Instruction, vol. 10, no.4, pp. 145-164, 2017

[7] S. Z. M. Osman, R. Jamaludin, and N. E. Mokhtar, "Flipped classroom and traditional classroom: lecturer and student perceptions between two learning cultures, a case study at malaysian polytechnic," International Education Research, vol. 2, no. 4, pp. 16-25, 2014.

[8] C.-Y. Chang, C.-H. Kao, and G.-J. Hwang, "Facilitating students' critical thinking and decision making performances: A flipped classroom for neonatal health care training," Educational Technology \& Society, vol. 23, no. 2, pp. 32-46, 2020.

[9] N. Hamdan, P. E. McKnight, K. McKnight, and K. Arfstrom, "A review of flipped learning," Flipped Learning Network, 2013.

[10] H. O. K. Ahmed, "Flipped learning as a new educational paradigm: An analytical critical study," European Scientific Journal, vol.12, no.10, April 2016. 
[11] H. Al-Samarraie, A. Shamsuddin, and A. I. Alzahrani, "A flipped classroom model in higher education: A review of the evidence across disciplines," Education Tech Research Dev. Association for Educational Communications and Technology (AECT), 2019.

[12] A. K. Ilgu, N. J. Cherrez, and C. T. Jahren, "A systematic review of research on the flipped learning method in engineering education," British Journal of Educational Technology, vol. 49, no. 3, pp. 398-411, 2018.

[13] H. T. L. Huong, N. H. D. Huy, and N. N. Ha, "The flipped classroom: Using thematic teaching to develop critical thinking for high school students," American Journal of Educational Research, vol. 6, no. 6, pp. 828-835, 2018.

[14] B. Means, Y. Toyama, R. Murphy, M. Bakia, and K. Jones, Evaluation of Evidence-Based Practices in Online Learning: A Meta-Analysis and Review of Online Learning Studies, U.S. Department of Education, 2010.

[15] S. Dehghanzadeh and F. Jafaraghaie, "Comparing the effects of traditional lecture and flipped classroom on nursing students' critical thinking disposition: A quasi-experimental study," Nurse Education Today, 2018

[16] S. M. Forood and A. A. K. Farahani, “A comparative study between the performance of Iranian high and low critical thinkers on different types of reading comprehension questions," Theory and Practice in Language Studies, vol. 3, no. 9, pp. 1710-1716, September 2013.

[17] E. R. Lai, "Critical thinking: A literature review," Pearson's Research Report, p. 4, June 2011

[18] M. Young and D. L. Warren, "Encouraging the development of critical thinking skills in the introductory accounting courses using the challenge problem approach," Issues in Accounting Education, vol. 26, no. 4, pp. 859-881, 2011.

[19] P. A. Facione, Critical Thinking: What It Is and Why It Counts, Measured Reasons LLC, pp. 1-30, 2015.

[20] D. E. Halpern, "Teaching critical thinking for transfer across domains, dispositions, skills, structure training, and metacognitive monitoring," American Psychologist, vol. 53, no. 4, pp. 449-455, 1998.

[21] S. A. Živkoviü, "A model of critical thinking as an important attribute for success in the 21st century," Procedia - Social and Behavioral Sciences 232, pp. $102-108,2016$.

[22] Z. Zainuddin, and S. H. Halili, "Flipped classroom research and trends from different fields of study," International Review of Research in Open and Distributed Learning, vol. 17, no. 3, pp. 313-340, 2016.

[23] F. Kohlbacher, "The use of qualitative content analysis in case study research," Forum: Qualitative Social Research, vol. 7, no. 1, art. 21, 2006.

[24] D. Moher, L. Shamseer, M. Clarke, D. Ghersi, A. Liberati, M. Petticrew, P. Shekelle, L. A. Stewart, and PRISMA-P Group, "Preferred reporting items for systematic review and meta-analysis protocols (PRISMA-P) 2015 statement," Systematic Reviews, vol. 4, no.1, 2015.

[25] R. A. Rasheed, A. Kamsin, and N. A. Abdullah, "Challenges in the online component of blended learning: A systematic review," Computers \& Education, vol. 144, p. 103701, 2020.

[26] J. O'Flaherty and C. Phillips, "The use of flipped classrooms in higher education: A scoping review," Internet and Higher Education, vol. 25 , pp. 85-95, 2015.

[27] S. C. Kong, "An experience of a three-year study on the development of critical thinking skills in flipped secondary classrooms with pedagogical and technological support," Computers \& Education, vol. 89, pp. 16-31, 2015.

[28] P. Etemadfar, S. M. A. Soozandehfar, and E. Namaziandost, "An account of EFL learners' listening comprehension and critical thinking in the flipped classroom model," Cogent Education, vol. 7, no. 1, pp. $1-22,2020$.

[29] Z. Atwa, R. Din, N. Othman, and M. Hussin, "Evaluating contribution of flipped learning on secondary students' critical thinking skills toward learning physics in palestine," International Journal of Engineering \& Technology, vol. 7, no. 4.21, pp. 53-57, 2018.

[30] M.J.V. Fulgueras and J. C. Bautista, "Flipped classroom: Its effects on ESL learners' critical thinking and reading comprehension levels," International Journal of Language and Literary Studies, vol. 2, Issue 3, 2020.

[31] M. Kloppers and M. J. Vuuren, "Enhancing critical thinking dispositions in the mathematics classroom through a flipped learning approach," Journal of Communication, vol. 7, no.1, pp. 151-160, 2016.

[32] L. R. DeRuisseau, "The flipped classroom allows for more class time devoted to critical thinking," Adv Physiol Educ, vol. 40, pp. 522-528, 2016.

[33] Y.-H. Lee, 'Scripting to enhance university students' critical thinking in flipped learning: Implications of the delayed effect on science reading literacy," Interactive Learning Environments, pp. 1-14, August 2017.

[34] M. L. Styers, P. A. V. Zandt, and K. L. Hayden, "Active learning in flipped life science courses promotes development of critical thinking skills," CBE-Life Sciences Education, vol. 17, ar39, pp. 1-13, 2018.

[35] M. Ibrahim, N. Khairudin, and D. Salleh, "Innovation of flipped learning encouraging better communication and critical thinking skills among accounting students," Journal of Physics: Conf. Series 1019, 2018.

[36] T. E. Smith, P. S. Rama, and J. R. Helms, "Teaching critical thinking in a GE class: A flipped model," Thinking Skills and Creativity, vol. 28, pp. 73-83, 2018.

[37] M. R. A. Chen and G. J. Hwang, "Effects of a concept mapping-based flipped learning approach on EFL students' english speaking performance, critical thinking awareness and speaking anxiety," British Journal of Educational Technology, vol. 0, no. 0, pp. 1-18, 2019.

[38] V. S. Andrini, H. Pratama, and T. W. Maduretno, "The effect of flipped classroom and project based learning model on student's critical thinking ability," Journal of Physics: Conf. Series 1171, 2019.

[39] B. A. Jensen, "Using flipped learning to facilitate cross-cultural critical thinking in the L2 classroom," A Journal of the American Association of Teachers of German, UP 52.1, pp. 50-68, 2019.

[40] L. Zheng, K. K. Bhagat, Y. Zhen, and X. Zhang, "The effectiveness of the flipped classroom on students' learning achievement and learning motivation: A meta-analysis," Educational Technology \& Society, vol. 23, no. 1, pp. 1-15, 2020.

[41] I. Blau and T. Shamir-Inbal, "Re-designed flipped learning model in an academic course: The role of co-creation and co-regulation," Computers \& Education, vol. 115, pp. 69-81, 2017.

[42] C. F. Herreid and N. A. Schiller, "Case study: Case studies and the flipped classroom," Journal of College Science Teaching, vol. 42, pp. $62-67,2013$

[43] A.M. Al-Zoubi and L.M. Suleiman, "Flipped classroom strategy based on critical thinking skills: Helping fresh female students acquiring derivative concept," International Journal of Instruction, vol.14, no.2, pp. 791-810, 2021.

[44] Y. Chen, Y. Wang, Kinshuk, and N. S. Chen, "Is FLIP enough? Or should we use the FLIPPED model instead?" Computers \& Education, vol. 79, pp. 16-27, 2014

[45] B. F. Hantla, "The effects of flipping the classroom on specific aspects of critical thinking in a christian college: A quasi-experimental, mixedmethods study," Ed.D. dissertation, Faculty of Southeastern Baptist Theological Seminary, Wake Forest, North Carolina, 2014.

[46] J. M. Saunders, "The flipped classroom: Its effect on student academic achievement and critical thinking skills in high school mathematics," Ed.D. dissertation, Liberty University, 2014.

[47] M. J. Dusenbury, "The effects of flipped learning on critical thinking disposition among undergraduate college students," Ph.D. dissertation, Graduate Faculty of the University of North Dakota, 2016.

[48] P. Brown, "A mixed method study: Assessing critical thinking, metacognition, and motivation in a flipped classroom instructional model," Ph.D. dissertation, Graduate School, the College of Education and Human Sciences and the School of Education at The University of Southern Mississippi, 2019.

[49] M.W. Tolbert, "The relationship between the flipped classroom and critical thinking, academic performance, student perceptions, and student evaluations in an introductory psychology course," Ph.D. dissertation, University of Tennessee at Chattanooga, 2020.

Copyright $\odot 2022$ by the authors. This is an open access article distributed under the Creative Commons Attribution License which permits unrestricted use, distribution, and reproduction in any medium, provided the original work is properly cited (CC BY 4.0).

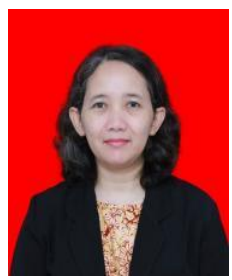

Benedecta Indah Nugraheni earned the S.Pd (bachelor in education) in accounting education from Sanata Dharma University, Yogyakarta, Indonesia in 1998; the M.Pd. (master in education) in educational technology from Yogyakarta State University, Indonesia in 2007; She is currently a lecturer in accounting education study Frogram, Faculty of Teacher Training and Education, Sanata Dharma University, Yogyakarta, and a doctor candidate at Yogyakarta State University. Her research interests include blended learning and learning media development. 
Herman Dwi Surjono is a professor at the College of Engineering and the Graduate School of the Yogyakarta State University, Indonesia. He got his master degree from the Iowa State University in 1995 $\mathrm{He}$ received his Ph.D. in information technology in 2006 from Southern Cross University Australia.

He teaches both undergraduate and graduate students computer programming, e-learning, interactive multimedia, and digital media. His research area includes adaptive hypermedia, computer based learning, and e-learning. He has experiences in providing consulting and training and development of Moodle based e-learning. He has published articles and books related to e-learning and multimedia. His goal is to empower teachers to optimize the use of e-learning in schools.

Prof. Surjono is a head of Instructional Technology Department at the Graduate School of YSU. He is a Senior Member No: 80343064
International Association of Computer Science and Information Technology (IACSIT) since 2011.

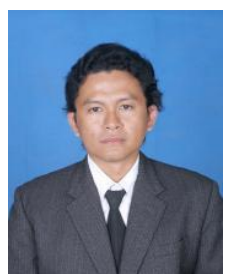

Gregorius Punto Aji earned the S.Pd. (bachelor in education) in English language education from Sanata Dharma University, Yogyakarta, Indonesia in 1998; the M.Hum. (master in humanistic studies) in English language studies, concentrating in English language teaching from Sanata Dharma University in 2007; He is currently a lecturer in English language education study program, Faculty of Teacher Training and Education, Sanata Dharma University, Yogyakarta. His research interests include language teaching methodology, autonomous learning, and critical thinking development. 